\author{
Research Article \\ www.ijrap.net (ISSN:2229-3566)
}

\title{
INTRODUCTION TO THE MANUSCRIPTS OF UPACHARASARA: A MEDIEVAL MEDICAL TEXT WRITTEN BY MUKUNDA DAIVAJNA
}

\author{
Rekha Sakkari ${ }^{1 *}, \mathrm{~S}$. M. Vaidya ${ }^{2}$, Chetan $\mathrm{M}^{2}$ \\ ${ }^{1}$ Assistant Professor, Department of Ayurveda Samhita and Siddhanta, Shri Veera Pulakeshi Rural Ayurvedic Medical \\ College and Hospital, Badami, Bagalkot, Karnataka, India \\ ${ }^{2}$ Professor, Department of Ayurveda Samhita and Siddhanta, Sri Dharmasthala Manjunatheshwara College of Ayurveda \\ and Hospital, Hassan, Karnataka, India
}

Received on: 08/05/20 Accepted on: 07/07/20

\author{
*Corresponding author \\ E-mail: rekha.sakkari@gmail.com
}

DOI: 10.7897/2277-4343.110497

\begin{abstract}
The manuscripts preserve acts as valuable treasure of knowledge which can be utilized for the wellbeing of present generation as well as to pass on to the next generation. Manuscripts possess many things like Jyotishya Shastra, Ayurveda Shastra and Prani Shastra etc. For the better understanding of contents of Ayurveda Manuscripts, the research study should be taken by Ayurveda physicians. As Ayurveda has its strong fundamentals, on which practical applications are deduced. The fundamental books of Ayurveda like Brihat Trayi, Laghu Trayi and other textbooks of Ayurveda are the achievements of proper manuscript studies. For gaining of further knowledge of Ayurveda, still more works are needed. A thorough study on Upacharasara, present in the form of manuscript in oriental research institute libraries has been brought much information that is new for present understanding. The present study focuses on various preventive and curative aspects of medicines for better development of Ayurveda practices. The major contents of this text can be made fewer than three major headings. They are the subject deal with Dravyadi Jnana (various concepts including Dravya), Roga Jnana (information about diseases) and Chikitsa Jnana (medicinal treatments). The underlying medical knowledge in Upacharasara is a huge contribution to the Ayurveda fraternity. The study is based on the technical method of critical edition in order to update and conserve the medical knowledge dealt in Upacharasara.
\end{abstract}

Keywords: Critical Edition, Dashanga Ayurveda, Mantra Chikitsa, Mukunda Daivajna, Upacharasara etc.

\section{INTRODUCTION}

Deciphering a manuscript, critical edition and its publication into a text is a journey to observe the study material through an authentic experimentation ${ }^{1}$. Conclusive factors of the contextual text are prepared through the series of unexplored and unidentified thoughts. The evaluation of the thought process is rightly to be well acquainted in the modified form without varying the meanings or keeping the meanings in its real form. A comprehensive and compact clarification is essentially incubated through the processing of the transcription of knowledge. Critical edition of a medical manuscript is different from the other literary works and as its extension is supplemented by verification of the context considering the different logarithms.

Upacharasara is such a medical manuscript which explains about the treatment in various aspects. It is written by Mukunda Daivajna son of Ranganatha and commentary named as Gudaprakashika by Dinakara Jyothisha ${ }^{2}$. Upacharasara manuscript is arranged in 5 chapters and deals with concept of treatment based on Dashanga Ayurveda.

1. Dravyajnapti Nirupana

2. Rogavyakti Nirupana

3. Kwathadhi Nirupana

4. Prakirnaadhikara Nirupana

5. Rasadyupachara Nirupana

The present manuscript consists of various preventive and curative aspects of treatments in different types of diseases and the contributions of Upacharasara of Mukunda Daivajna to the field of Ayurveda is also more.

\section{Objectives of the study}

- To collect and decipher the manuscripts on Upacharasara by Mukunda Daivajna.

- To collate and critically edit the manuscripts on Upacharasara by Mukunda Daivajna.

\section{Methodology}

The study is based on five manuscripts and all are in Devanagari (Dn) script.

Dn-1 - Obtained from ORI, Baroda; Accession number -1622.

Dn-2 - Obtained from BORI, Pune; Accession number -86/190715 ,

Dn-3 - Obtained from BORI, Pune; Accession number-587/1899-

1915 ,

Dn-4 - Obtained from BBRAS, Mumbai; Accession number-167, and

Dn-5 - Obtained from BISM, Pune; Accession number-1590 (Incomplete).

Digitalization of manuscripts, editing and analysis of mutual relationship among collected copies of manuscripts, transliteration of all extant of copies selected for critical edition and English translation of the text are the part of work. 


\section{About author}

According to internal and external evidences of manuscripts, the author of the text Upacharasara is Mukunda Daivajna or Mukunda Ganaka son of Ranganatha Ganaka ${ }^{3}$. In this manuscript the author himself has not revealed the time period and place of birth. At the end colophons of each manuscript suggests that the regional year of manuscript and most of the Ganaka family located in Madhya Pradesh, Maharashtra and North Karnataka states of ancient India. By these evidences, the time period of author can be considered approximately $18^{\text {th }}$ century and the place is near Poona of Maharashtra state ${ }^{4}$. The author has explained Sadhya-Asadhya of roga lakshana based on Jyotishya Shastra; this evidence indicates author was a well-known Sanskrit scholar and Astrologer.

\section{About commentator}

The commentator of the Upacharasara is Dinakara Jyothisha and the name of commentary is Gudaprakashika.

\begin{abstract}
About the text
The text is considering various aspects of curative and preventive medicines in different diseases. The text is presented in the form of Devanagari script and Sanskrit language and Anushtup style of Chanda prakara. The initial part of manuscript shows about Hinduism of author as mentioned as "Shri Ganeshayanamah, Shri Sarswatyeyanamah and Shri Laxmivenkateshayanamah". The end colophon indicates the year of the manuscript as described as "Khasamudrashwa Bhushake Bahudhanya Samvathsare Karthike Purvapakshe Chaturthyamiduvasare" and in other manuscript "Shake 1756 Jayanama Samvathsare Ashwinshuddha 15 Bhruguvaare Revathi Nakshatra Dine Sampurnam". By considering these evidences it can be assumed that the author Mukunda Daivajna written Upacharasara in and around $18^{\text {th }}$ Century AD.
\end{abstract}

Total five manuscripts are collected in different Oriental Research Institutions and Manuscript Libraries from India i.e. shown in the Table 1.

Table 1: Source of Data

\begin{tabular}{|c|c|c|c|c|c|c|}
\hline S. No & Manuscript Name & Author & Source & Accession No. & Folio No's & Regional year \\
\hline 1 & Upacharasara & $\begin{array}{l}\text { Mukunda } \\
\text { Daivajna }\end{array}$ & $\begin{array}{l}\text { Oriental Research Institute } \\
\text { Baroda }\end{array}$ & 1622 & 68 & 1716 \\
\hline 2 & Upacharasara & $\begin{array}{l}\text { Mukunda } \\
\text { Daivajna }\end{array}$ & $\begin{array}{c}\text { Bhandarkar Oriental Research } \\
\text { Institute Pune }\end{array}$ & $\begin{array}{c}86 / 1907 \\
- \\
15\end{array}$ & $42+2$ & 1736 \\
\hline 3 & Upacharasara & $\begin{array}{l}\text { Mukunda } \\
\text { Daivajna }\end{array}$ & $\begin{array}{l}\text { Bhandarkar Oriental Research } \\
\text { Institute Pune }\end{array}$ & $\begin{array}{c}587 / 1899 \\
- \\
1915\end{array}$ & 121 & 1740 \\
\hline 4 & Upacharasara & $\begin{array}{l}\text { Mukunda } \\
\text { Daivajna }\end{array}$ & $\begin{array}{c}\text { Bombay Branch of Royal Asiatic } \\
\text { Society Mumbai }\end{array}$ & 167 & 139 & 1756 \\
\hline 5 & Upacharasara & $\begin{array}{l}\text { Mukunda } \\
\text { Daivajna }\end{array}$ & $\begin{array}{c}\text { Bharat Itihasa Samshodhak } \\
\text { Mandal Pune }\end{array}$ & $1590(\mathrm{INC})$ & 54 & - \\
\hline
\end{tabular}

Figure of Digitalized copies of Upacharasara manuscripts

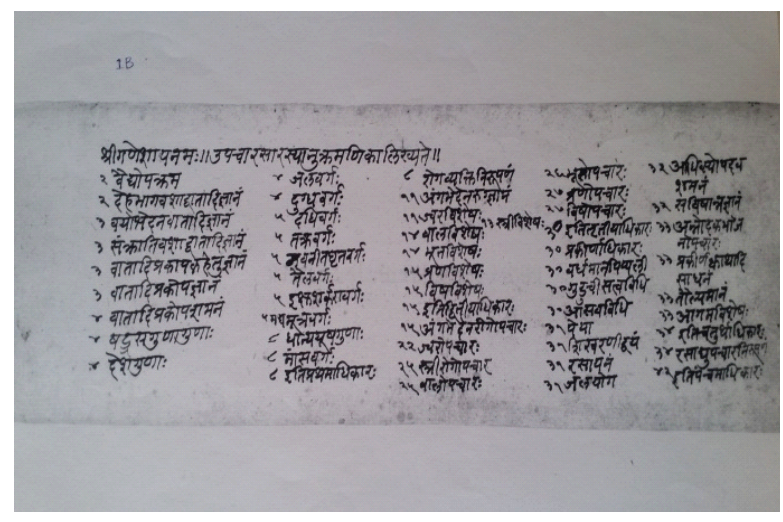

Dn-2-obtained from BORI

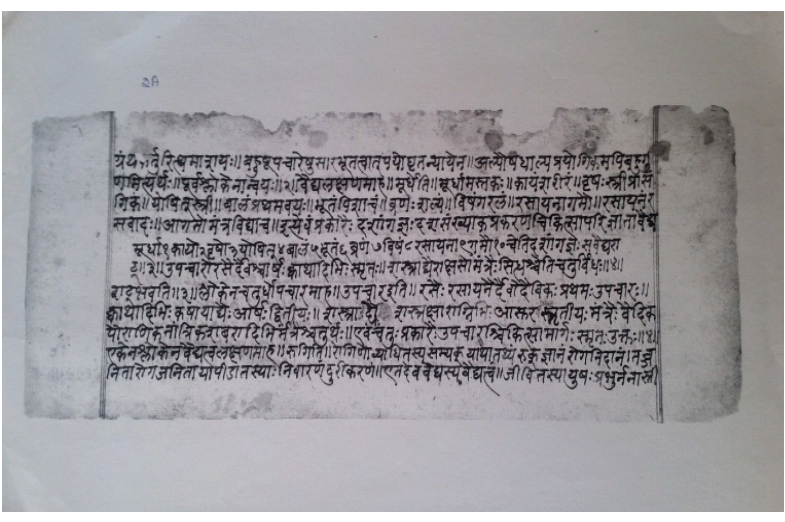

Dn-3 obtained from BORI

Figure 1 and 2: Digitalized copies of Manuscripts

\section{Brief contents of the text}

\section{Prathama Adhikarana-Dravyajnapthi Nirupana}

This chapter deals basic knowledge about Ayurveda Vaidyopakrama, Dashanga Ayurveda (Ten branches of Ayurveda-Murdha, Kaya, Vrusha, Yoshit, Baala, Bhuta, Vrana, Visha, Rasayana and Agama chikitsa), Vatadi Doshajnana, Shadrasa Guna-Aguna, Jala-Dugda-Taila-Navaneeta-Grita-
Mamsa-Phala-Kandha-Mula-Patra-Guda etc; drava-dravya and Annadravyadi varga.

\section{Dwitiya Adhikarana-Rogavyakti Nirupana}

It deals with nidana and lakshana of different diseases are mentioned under seven important headings i.e. Angabhedena ruk Jnana (the diseases are related to Urdhvajatrugata roga, Amashayagata roga, Pakvashayagata roga), Jwara vishesha (Nadi Pariksha, different types of Nadi lakshana and Jwara lakshana), 
Stree vishesha (Artavajanya, Garbhajanya and Stanya roga), Baala vishesha (Shishurodhana, Danta dosha, Talu-Jivha-Kantha roga etc.), Bhuta vishesha (Grahadi roga), Vrana vishesha (Pakvavrana etc.) and Visha vishesha (Sarpavisha, Paradajanya, Maadaka dravya janya visha etc).

\section{Tritiya Adhikarana-Kwathadi Nirupana}

It deals with upachara (treatment methods) of different diseases which are mentioned in Rogavyakti Nirupana (Dwitiya Adhikarana) in the form of various formulations like Kwatha, Lepa, Anjana, Pana, Raktamokshana etc. external and internal formulations and Mantra chikitsa for Bhutadi and Vishadi Roga.

\section{Chaturtha Adhikarana-Prakirnadhikara Nirupana}

The remaining treatment methods explained in this Chapter, which are not dealt in the Kwathadi Nirupana (Tritiya Adhikarana) like Rasayana yoga (Vardhamana pippali, Jala prayoga), Vamana-Virechana yoga, Pathya kalpana (Peya), Bhaishajya kalpana (Asava, Guduchi satva etc.), Savishanna Jnana etc.

\section{Panchama Adhikarana: Rasadyupachara Nirupana}

Various Rasaushadhis yoga is explained in this chapter. For example, Rasa Sindura, Shiva, Bhanu, Surya, Chandrachuda, Garbapalana and Tamakahara etc. total ninety-three yoga are mentioned for different diseases.

\section{RESULT}

The word meaning of Upacharasara indicates valuable or appreciable treatment, as the subject is concerned more about various concepts and treatment for different diseases with uses of herbals and minerals.

The original manuscripts of Upacharasara are searched through Descriptive catalogue of Sanskrit manuscripts published by BORI
(Pune $^{5}$, CCRAS catalogue ${ }^{6}$ and New Catalogus Catalogorum, Volume 2 (Madras) $^{7}$. It is collected in five different Oriental Research Manuscript Libraries in India. Those are written by Mukunda Daivajna. Based on internal and external evidences identified as the author place was near Poona of Maharashtra and time of birth was fixed as around $18^{\text {th }}$ century and the author has given lot of contribution to the field of Jyotishya Shastra as well as Ayurveda. Lots of similarity are seen between Mukunda Daivajna's Upacharasara when it has been compared with texts of $18^{\text {th }}$ century namely Visha tantra, Jyotishya Shastra and even with Haramekhala like Prakrit texts ${ }^{8}$. Because the diseases such as Jhinjhini vata, Jhallakhya roga, Godharya roga, Govare roga, Khanjini roga and Khalvatadi roga are the names which are used in all these texts mentioned above. Jyotishya Shastra was fully developed at the later part of $17^{\text {th }}$ century and Mukunda Daivajna was an eminent Astrologer by his caste.

The period of $18^{\text {th }}$ and $19^{\text {th }}$ centuries in India is considered by all scholars as modern period. This is the period of ending of Mughal empire and establishment of British rule has been started. In this situation, number of literatures on modern as well as Ayurveda were established by the end of $17^{\text {th }}$ century and in $18^{\text {th }}$ century fully developed treatment specialties like Mantra chikitsa, Marana, Homa as well as Mutra Pariksha, Nadi Pariksha were being used in treating and understanding the diseases stages. The various chikitsa yoga like Ekamulika and Rasaushadhis and even simple Rasayana yoga will help physicians to adopt them quickly in curing the diseases. These all aspects might have influenced the author Mukunda Daivajna to compose a text in $18^{\text {th }}$ century with the name of Upacharasara. Upacharasara is one of the such a kind of medical manuscript, the author has given prime importance to physicians, various diseases related to Dashanga Ayurveda and their treatment based on Drava-dravyadi and Mantra chikitsa. By this assumed that society needs preventive and curative aspects of medicines in this era.

The commentator of this manuscript is Dinakara Jyothisha, commentary named as Gudaprakashika and the birthplace was Golappa (near Poona of Maharashtra).

Upacharasara manuscripts are distributed in the form of total five chapters and 612 shloka. (Based on Devanagari Dn1 manuscript)

Table 2: Distribution of Chapters

\begin{tabular}{|c|c|c|c|}
\hline S. No. & Chapters names & Total no of verses & Distribution of folios \\
\hline 1 & Dravyajnapti Nirupana & 106 & 1B-7B \\
\hline 2 & Rogavyakti Nirupana & 100 & 7B-12B \\
\hline 3 & Kwathadhi Nirupana & 210 & $13 \mathrm{~A}-24 \mathrm{~A}$ \\
\hline 4 & Prakirnaadhikara Nirupana & 64 & $24 \mathrm{~B}-27 \mathrm{~A}$ \\
\hline 5 & Rasadyupachara Nirupana & 132 & $27 \mathrm{~B}-34 \mathrm{~A}$ \\
\hline
\end{tabular}

Total numbers of yoga of diseases

Table 3: Total Chikitsa Yoga

\begin{tabular}{|c|c|c|}
\hline S. No. & Diseases & Total Yogas \\
\hline 1 & Angabhedena upachara & 235 \\
\hline 2 & Jwaropachara & 53 \\
\hline 3 & Streerogopachara & 51 \\
\hline 4 & Baalarogopachara & 21 \\
\hline 5 & Bhutopachara & 05 \\
\hline 6 & Vranopachara & 12 \\
\hline 7 & Vishopachara & 28 \\
\hline
\end{tabular}

Meanwhile the following observations are noted during Critical edition of Upacharasara manuscript. 
Table 4: Observations of Manuscripts

\begin{tabular}{|c|c|}
\hline Marginal writings & Title of the work cited \\
\hline Kakapada & Author name cited \\
\hline Interlinear additions & Names of other authors cited \\
\hline Peculiar words & Names of the other texts cited \\
\hline Borrowed words & Distribution of diseases and treatment based on Dashanga Ayurveda \\
\hline Orthographic peculiarities & Ekamulika Dravya Prayoga \\
\hline Technical terms & Shreshta Dravya \\
\hline Scribal errors & Different synonyms of Dravya \\
\hline Meters used & Mana Paribasha etc. \\
\hline
\end{tabular}

\section{Genealogy}

Dn- 3, Dn-1 and Dn -2 are transmitted texts from autograph copy. Dn-4 follows Dn-3 and Dn-5 follows Dn-2. Dn -1 is separate manuscript where in no other manuscripts follow it.

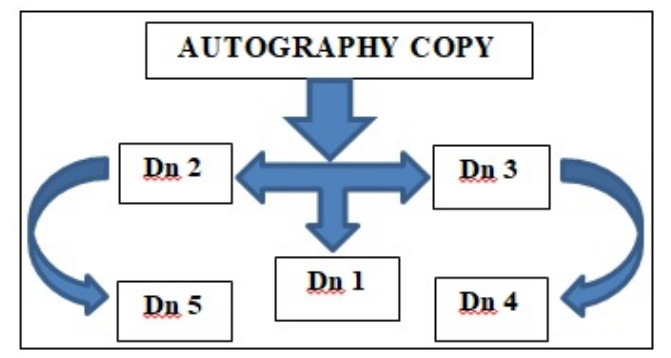

Figure 3: Autography copy

\section{CONCLUSION}

By observing all internal and external evidence, Upacharasara by Mukunda Daivajna son of Ranganatha Daivajna was well known Sanskrit scholar and Astrologer pertaining to $18^{\text {th }}$ CAD. Upacharasara deals with the various concepts like Dashanga Ayurveda, Vaidyopakrama, Tridosha Jnana, Drava-dravyadi varga along with lakshana of diseases and their treatment modalities. All of these are described systematically in five Adhikarana (chapters) of Upacharasara with unique and lucid manner i.e. Dravyajnapti Nirupana, Rogavyakti Nirupana, Kwathadyupachara Nirupana, Prakirnaadhikara Nirupana and Rasadyupachara Nirupana. The sequence that followed in the Upacharasara starts from basic knowledge of Ayurveda like branches of Ayurveda, Dravya etc. and ends with mantra chikitsa by covering ten branches of Ayurveda (Dashanga of Ayurveda). Thus, provides a concrete illustration on fundamental and treatment modalities of Ayurveda. Mukunda Daivajna gives unique contribution like this by composing Upacharasara.

Dashanga Ayurveda, various new diseases and their treatment with various formulations, Ekamulika Prayoga, Shreshta Dravya, Rasayoga for disorders and Mantra chikitsa for Bhutadi and Vishadi Roga are the unique contributions of Upacharasara. These all contributions enhance the richness of Ayurveda in modern era.

\section{REFERENCES}

1. Greeshma Mahesh. Vaidya SM. Editing The Text: Modus Operandi. UJAHM 2019; 07(04): 13-18.

2. Sharma PV. Ayurveda Ka Vaijnanik Itihasa. Kayachikitsa: Anya Chikitsa Grantha. Reprint edition. Varanasi: Chaukhambha Orientalia; 2012. p. 326.

3. Meaningful thoughts. Ganaka Ayurveda. India: WordPress.com; October 26, [cited 2018 Jan 26]. Available from: https://meaningfulthoughts.wordpress.com; 2010.

4. Dominik Wujastyk. A pilot census of the medical sciences in Sanskrit. Journal of Indian Institute of History of Medicine 2008; Vol. 38: 111-156.

5. Sharma HD. Descriptive Catalogue of Sanskrit manuscripts. $1^{\text {st }}$ edition. Poona: Published by Bhandarkar Oriental Research Institute; 1939. p. 33-36.

6. Rama Rao B. Sanskrit Medical Manuscripts in India. New Delhi: Published by Central Council for Research in India Medicine and Homeopathy; 1972. p. 64.

7. Raghavan V. New Catalogus Catalogorum, Revised edition. Madras: Published by University of Madras; 1968. Vol II. p. 345.

8. Manas Ajay. Critical Edition of Haramekhala ( $4^{\text {th }}$ Paricheda)A Medieval Medical Text, MD (Thesis). Karnataka: Rajiv Gandhi University of Health Sciences; 2016.

\section{Cite this article as:}

Rekha Sakkari et al. Introduction to the manuscripts of Upacharasara: A Medieval medical text written by Mukunda Daivajna. Int. J. Res. Ayurveda Pharm. 2020;11(4):99-102 http://dx.doi.org/10.7897/2277-4343.110497 